\title{
Pharmacognostic Studies of the Leaves of Hyptis Suaveolens Linn. (Labiatae) (Poit)
}

\author{
Eleje Oboma Okonta, Peculiar Feenna Onyekere, Patience Ngozi Ugwu*, Helen Ogechukwu Udodeme, \\ Vincent Obisike Chukwube, Uchenna Estella Odoh and Christopher Obodike Ezugwu
}

\section{Eleje Oboma Okonta, Peculiar Feenna Onyekere, Patience Ngozi Ugwu*, Helen Ogechukwu Udodeme, Vincent Obisike Chukwube, Uchenna Estella Odoh and Christopher Obodike Ezugwu}

Department of Pharmacognosy and Environmental Medicines, Faculty of Pharmaceutical Sciences, University of Nigeria, Nsukka, NIGERIA.

\section{Correspondence}

\section{Patience Ngozi Ugwu}

Department of Pharmacognosy and Environmental Medicines, Faculty of Pharmaceutical Sciences, University of Nigeria, Nsukka, NIGERIA.

E-mail: peculiar.onyekere@unn.edu.ng History

- Submission Date: 12-01-2021;

- Review completed: 18-03-2021;

- Accepted Date: 29-03-2021.

DOI : 10.5530/pj.2021.13.89

Article Available online http://www.phcogj.com/v13/i3

\section{Copyright}

(C) 2021 Phcogj.Com. This is an openaccess article distributed under the terms of the Creative Commons Attribution 4.0 International license.

\begin{abstract}
The pharmacognostic standards of fresh, powdered and transverse sections of Hyptis suaveolens (L.) leaf were carried out to determine its macroscopic, microscopical (both qualitative and quantitative), analytical standards and phytochemical profile. The macroscopy revealed a simple leaf, oppositely arranged along the stem with a dark green colour on the outer surface and pale green on the inner surface, ovate in shape and bilateral base, acute apex with a serrate margin. The qualitative microscopy of the powdered leaf shows xylem vessels parenchymal cells with diacytic type of stomata. Also epidermal cells with stoma wall, polygonal parenchymatous and collenchymatous cells making up the cortex with starch grains; non-glandular uniserate, multicellular septate trichome, irregular shaped prisms of calcium oxalate crystals and small bundle of mucilage cells. The quantitative microscopy of the leaf showed the values of palisade ratio, stomatal number (upper and lower epidermal stomatal index (upper and lower surface), vein-islet number and vein termination number to be $5.10,50$ stomata $/ \mathrm{mm}^{2}, 80$ stomata $/ \mathrm{mm}^{2}, 12.33,23.14,35 / \mathrm{mm}^{2}$ and $20 / \mathrm{mm}^{2}$ respectively. For the analytical standards; $9.90 \%, 1.67 \%, 0.38 \% 6.39 \%, 0.61 \% \mathrm{w} / \mathrm{w}, 1.16 \% \mathrm{w} / \mathrm{w}, 11.70$ $\%$ and $7.25 \%$ were obtained for total ash, water soluble ash, sulphated ash, acid insoluble ash, alcohol soluble extractive value, water soluble extractive value, moisture content and fibre content respectively. The qualitative phytochemical analysis on Hyptis Suaveolens leaves showed presence of carbohydrates, reducing sugar, tannins, flavonoids, steroids, glycosides, terpenoids, alkaloids and saponins. These specific standards obtained are of importance in the establishment of diagnostic indices for the standardization, identification and preparation of monograph on the plant.
\end{abstract}

Key words: Hyptis Suaveolens L. (Poit), Pharmacognostic standards, Microscopy, Macroscopy, Analytical standards, Phytochemical analysis.

\section{INTRODUCTION}

Hyptis Suaveolens (L.) originally native to tropical America, is widespread in tropical Africa, Asia and Australia. It is now considered a weed worldwide. ${ }^{1}$ It is commonly called curry leaf, and locally in Northern Nigeria as Daddoyata-daji in Hasua; Efiri in Yoruba and Tanmotswangi Kha ${ }^{2}$ It is commonly called in Thai as Maeglak, ${ }^{3}$. It is known to be used in traditional medicine for treatment of various illnesses and the essential oil possesses insecticidal and larvicidal properties ${ }^{4}$. The morphological parts of this plant have various ethno-medicinal uses. The decoction of the roots is used as an appetizer. The leaves have been utilized as a stimulant, carminative, sudorific, galactogogue and as a cure for parasitic cutaneous diseases ${ }^{5}$. The root is chewed with betel nuts as a stomachic ${ }^{6}$. The leaves and twigs are claimed to have anti-spasmodic effect and are used to treat rheumatism, it is also used in anti-soporific baths, as anti- inflammatory and anti-fertility agents ${ }^{7}$. It is applied in burns, wounds and various skin complaints. Fresh leaves of Hyptis suaveolens (Figure 1) are kept at the entrance and windows in homes to repel mosquitoes. Fumes from burning dried leaves are used to repel mosquitoes and control insect pests from stored grains. The leaves are used to treat cancer ${ }^{7}$. The Ethyl acetate extract of Hyptis suaveolens exhibited significant Larvicidal activity compared to the Methanol and Chloroform extracts ${ }^{8}$. Owing to its various reported medicinal uses, there is a need to establish the microscopic, macroscopic and analytical standards of the plant to avoid adulteration. The aim of this study is to investigate the pharmacognostic standards of this plant so as to obtain its diagnostic characters, thereby establishing diagnostic indices that will be useful in evaluation of the purity, quality, safety and standardization of the crude drug sample.

\section{MATERIALS AND METHODS}

\section{Collection, identification and preparation of plant materials}

The samples of Hyptis suaveolens were collected from Alor Unor in Nsukka Local Government in Enugu state of Nigeria in December 2019. They were identified and authenticated by Mr. Felix Nwafor, Botanist of the Hebarium, Department of Pharmacognosy and Environmental Medicines, Faculty of Pharmaceutical Sciences, University of Nigeria, Nsukka. The voucher specimen was deposited at the Department and assigned the 


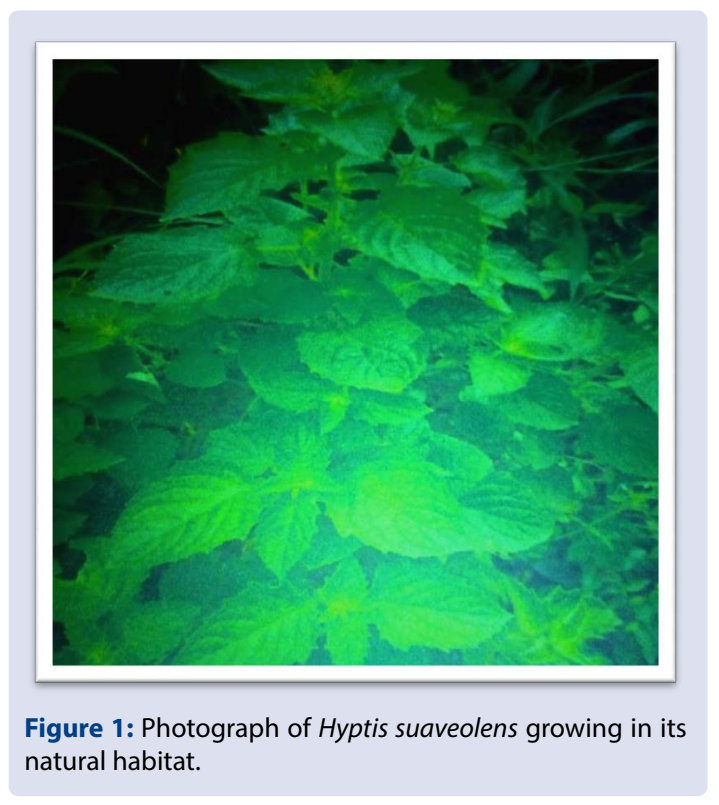

number - PCG/UNN/0325. The fresh leaves of Hyptis Suaveolens were air-dried under shade, pulverized and the leaf powder was used for pharmacognostic studies.

\section{Phytochemical analysis}

Chemical tests were performed on the powdered leaf in order to detect the presence or absence of major secondary plant metabolites of pharmacognostic importance using standard methods. ${ }^{9,10 .}$

\section{Pharmacognostic standardization}

\section{Macroscopic examination of the leaves}

The fresh leaves of Hyptis suaveolens were virtually examined using the methods described by Evans ${ }^{11}$. The macroscopic features of the leaves which include type of margin, shape, base, apex, venation, size, mid-rib, surface character and texture were observed and noted. The organoleptic properties such as colour, odour and taste of the plant materials were also observed and noted.

\section{Microscopic examination of powdered leaves}

\section{Quantitative microscopy}

This was determined following standard methods ${ }^{11}$. A constant range of values for palisade ratio, stomatal number, stomata index, vein-islet number and veinlet termination number were obtained.

\section{Qualitative microscopy}

Sample of the leaf powder was placed on the slide, two drops of chloral hydrate solution was added to moisten the powder and also act as a clearing agent. The slide was passed across the flame of a Bunsen burner repeatedly until bubbles occurred. It was allowed to cool, the slide was covered with glycerin followed with cover slip and was viewed under the photomicroscope (magnification $\times 100$ ). The microscopic characters were observed and noted.

\section{Microscopic examination of transverse section}

An anatomic section of the fresh leaf was prepared for the microscopic studies. The staining was done using standard methods ${ }^{12}$. The transverse section was done by sectioning of the specimen using a sledge micrometer. It was transferred into a staining jar and stained in safranin for 5 minutes. The section was washed with distilled water, followed with alcohol, and thereafter stained again with $1 \%$ fast green for 5 minutes and washed with absolute alcohol. It was transferred into a jar containing 50/50 alcohol/xylene and washed until they became clear. The section was cleared chloral hydrate solution and mounted on a slide with dilute glycerine.

\section{Determination of analytical standards}

The qualitative and quantitative analysis of the chief chemical constituents of the crude drugs, determination of the various ash values as well as solvent extractive values followed the specification as described in the British Pharmacopoeia. ${ }^{13}$

\section{RESULTS}

\section{Phytochemical analysis}

The results of the phytochemical screening of Hyptis suaveolens leaf are shown in Table 1 .

\section{Macroscopic examination of the whole leaf}

The macroscopic examination of the whole leaf of Hyptis suaveolens are shown in Table 2.

\section{Microscopy of the leaf powder}

The leaf microscopy of Hyptis suaveolens showed that the leaf is amphistomatic (stomata occur both on the adaxial and abaxial surfaces of the leaf). The stomata are of the diacytic type (there were presence of two subsidiary cells adjacent to the guard cells of the stomata). Also present were uniseriate multicellular covering trichomes and glandular trichomes. The photomicroscopy of the powdered leaf showed a number of features as shown in Figures 2-5.

\section{Quantitative microscopy of the leaf}

The quantitative microscopy of the leaf of Hyptis suaveolens gave values for palisade ratio, stomata number, stomatal index, vein-islet number and veinlet termination number as presented in Table 3 .

\section{Analytical standards of the leaf}

The analytical standards of the leaf of Hyptis suaveolens showed the composition of the total ash, water soluble ash, sulphated ash, acid insoluble ash, alcohol soluble extractive value, water soluble extractive value and moisture content as presented in Table 4. 
Table 1: Phytochemical Analysis of of Hyptis suaveolens.

\begin{tabular}{ccccc}
\hline S/N & Phytochemical & \multicolumn{3}{c}{ Inference } \\
1 & Class & EAF & CHF & ETF \\
2 & Carbohydrates & + & ++ & +++ \\
3 & Reducing Sugar & ++ & - & +++ \\
4 & Tannins & ++ & + & + \\
5 & Flavonoids & + & + & + \\
6 & Steroids & + & + & + \\
7 & Glycosides & + & ++ \\
8 & Terpenoids & + & + & + \\
9 & Alkaloids & + & + & + \\
\end{tabular}

Key: $\mathrm{EAF}=$ Ethyl Acetate fraction, $\mathrm{CHF}=$ Chloroform fraction, $\mathrm{ETF}=$ Ethanol fraction

$-=$ not present, $+=$ present,$++=$ present in moderately high quantity, $+++=$ present in very high quantity.

Table 2: Macroscopic Evaluation of Whole Leaf of Hyptis suaveolens.

$\begin{array}{lll}\text { S/N } & \text { Parameters } & \text { Observations } \\ 1 & \text { Colour } & \text { Dark green on the outer surface and pale green on the inner surface } \\ 2 & \text { Margin } & \text { Serrate } \\ 3 & \text { Apex } & \text { Acute } \\ 4 & \text { Composition of Lamina } & \text { Simple } \\ 5 & \text { Shape of Lamina } & \text { Ovate } \\ 6 & \text { Venation } & \text { Reticulate } \\ 7 & \text { Base } & \text { Bilateral } \\ 8 & \text { Size } & 18-19 \mathrm{~cm} \text { long and } 10-11 \mathrm{~cm} \text { wide are borne on the stalks } \\ 9 & \text { Surface } & \text { Pilose } \\ 10 & \text { Odour } & \text { Aromatic } \\ 11 & \text { Taste } & \text { Irritating } \\ 12 & \text { Texture } & \text { Pilose }\end{array}$

Table 3: Quantitative Microscopic Evaluation of Hyptis suaveolens.

\begin{tabular}{ccc}
\hline Parameters & & Values (stomata $/ \mathrm{mm}^{2}$ ) \\
\hline Palisade ratio & & 5.1 \\
Stomatal number: & upper epidermis & 50 \\
& Lower epidermis & 80 \\
Stomatal index: & upper surface & 12.33 \\
& Lower surface & 23.14 \\
Vein-islet number & & 35 \\
Veinlet termination number & & 20
\end{tabular}

Table 4: Analytical standards of Hyptis suaveolens.

\begin{tabular}{cc} 
Parameters & \% w/w composition \\
\hline Total ash & 9.9 \\
Water Soluble ash & 1.67 \\
Sulphated ash & 0.38 \\
Acid insoluble ash & 6.39 \\
Alcohol soluble extractive value & 0.61 \\
Water soluble extractive value & 1.16 \\
Moisture content & 11.7 \\
Fibre & 7.25
\end{tabular}



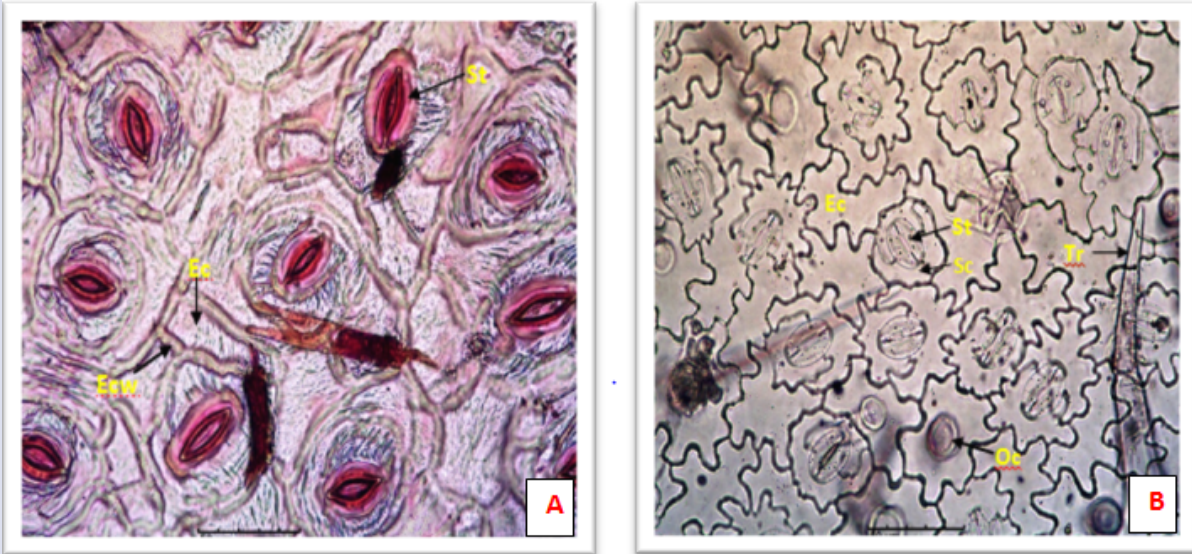

Figure 2: (A) Photomicrograph of leaf showing Adaxial (lower) surface of the leaf $H$. suaveolens. (B) Photomicrograph of leaf showing Adaxial (lower) surface of the leaf $H$. suaveolens. $\mathrm{Tr}=\mathrm{Trichome;} \mathrm{St}=$ stomata (diacytic); $\mathrm{Ec}=$ epidermal cell; $\mathrm{Sc}=$ subsidiary cell; $\mathrm{Oc}=$ oil cell.
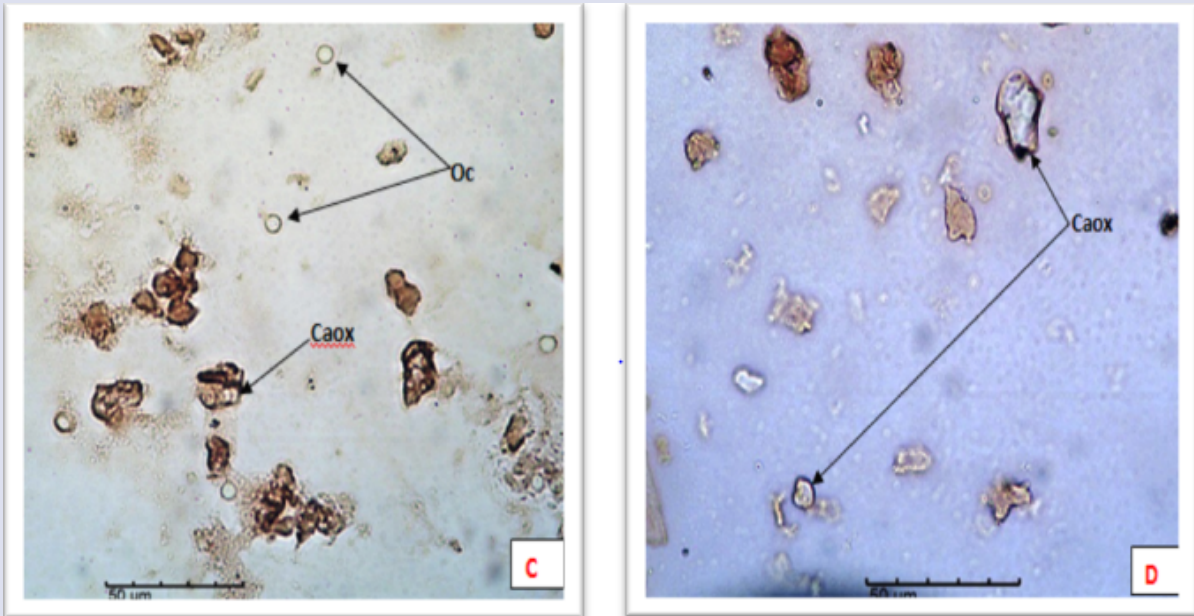

Figure 3: Chemomicrograph of the leaf powder showing round (C) and prism shaped (D) calcium oxalate crystals. Caox- Calcium oxalate crystals; Oc- Oil cells.
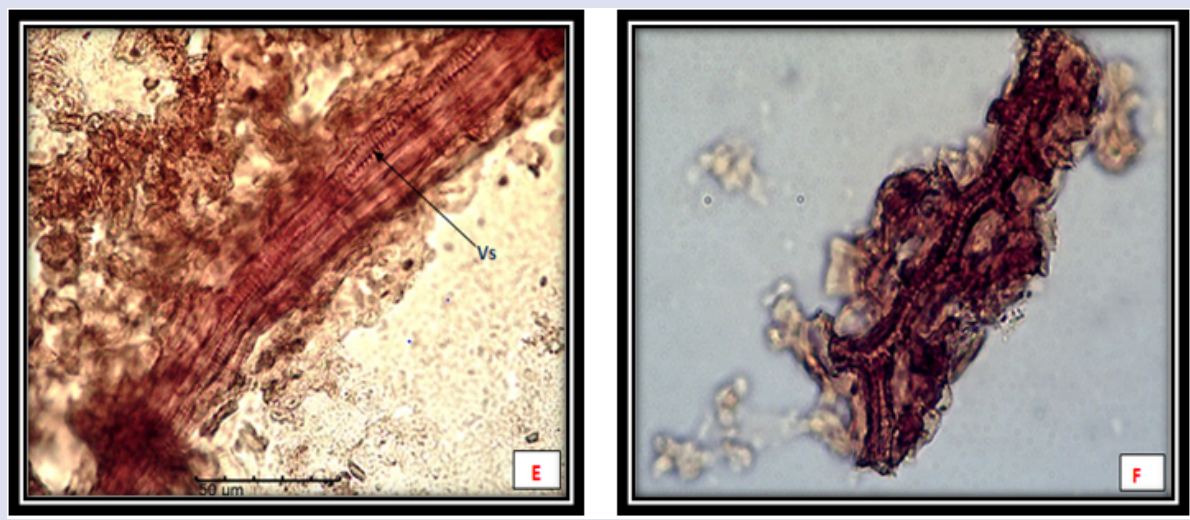

Figure 4: (E) Chemomicrograph of the leaf powder showing lignified tissues including reticulate and spiral vessels(Vs). (F)- Chemomicrograph of the leaf powder showing lignified xylem and phloem elements. 


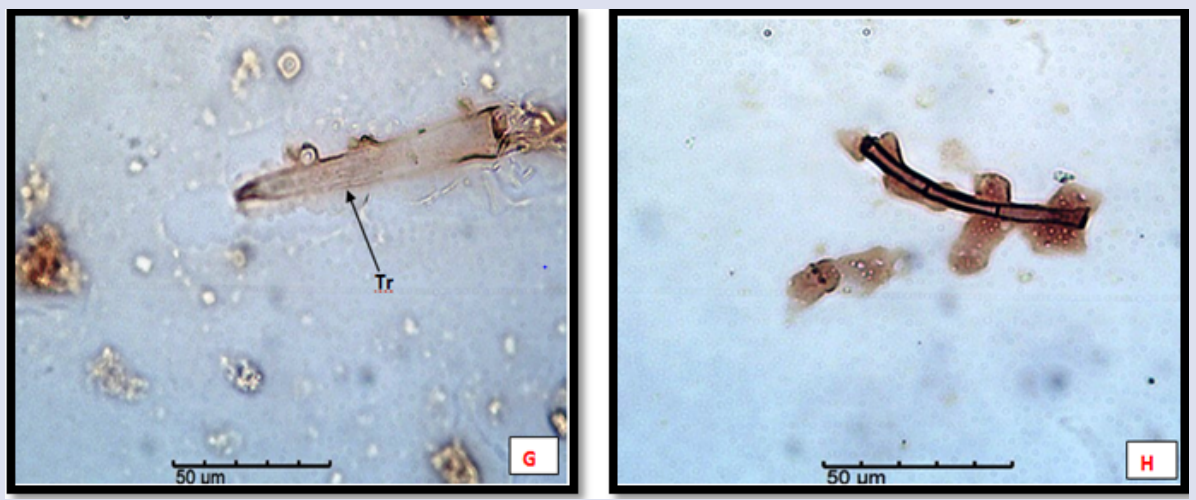

Figure 5: G- Chemomicrograph of the leaf powder showing a fragmented uniseriate covering trichome. (H)- Chemomicrograph of the leaf powder showing a fragmented uniseriate multicellular trichome.

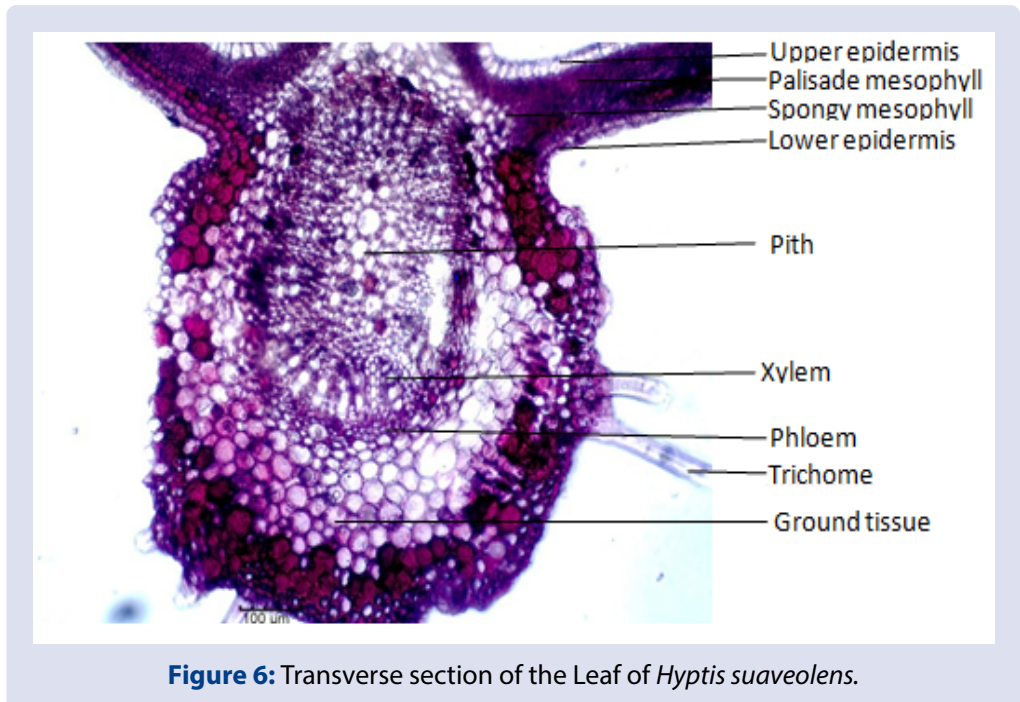

\section{Transverse section of the leaf}

The transverse section of the leaf of Hyptis suaveolens showed the outline of the microscopical characters present in the powdered leaf with a magnification of $\times 200$ as shown in Figure 6.

\section{Qualitative microscopy of the leaf}

Qualitative microscopical examination revealed the presence of epidermal cells with aniso stoma, xylem vessels, both unicellular and multicellular trichomes, bundles of fibre, palisade cells and prisms of calcium oxalate crystals as shown in Figures 2-5.

\section{DISCUSSION}

Phytochemical analysis of the extract and fractions revealed the presence of biologically active constituents like carbohydrates, reducing sugar, tannin, flavonoid, steroid, glycoside, terpenoid, alkaloid and saponin (Table 1). The presence of these phyto-chemical constituents have been reported in $H$. suaveolens ${ }^{8}$. The presence of secondary metabolites (i.e phytochemicals) in plants are known to confer pharmacological activities to the plant ${ }^{14}$. Pharmacognostic standardization of Hyptis suaveolens showed that it has a set of unique features with specific characteristics. With the macroscopic standards, the macroscopic characters of the leaves such as margin, venation, base, apex etc. were seen to be serrate, reticulate, bilateral and acute. The morphological organoleptic properties such as colour, odour and taste of the plant material were also seen to be dark green on the outer surface and pale green on the inner surface, aromatic and irritating. Qualitative microscopical examination revealed the presence of polygonal parenchymatous and collenchymatous cells making up the cortex, rectangular epidermal cells with palisade and spongy mesophyll cells attached, prisms of calcium oxalate crystals, non-glandullar uniserate multicellular septate trichome mucilage cells, (Figures 2-5). This feature in association with observable characters aided in the determination of stomata number, stomata index, vein-islet number, vein-islet termination number and palisade ratio. From the results (Table 3), the stomata index for the lower epidermis gave a higher value than for the upper epidermis which is correlating with recommended figures. The analytical standardization of Hyptis suaveolens powdered leaves were within pharmacopoeia standards and developed numerical standards which could be used as reference guides for their identification and assessment of their quality and purity. The total ash value was $9.90 \%$. The total ash value provides useful information on the level of quality, purity and appearance of a crude drug. The acid insoluble ash is more reliable than the total ash value. This is because the calcium carbonate yield by the incinerated oxalate which was soluble in dilute hydrochloric acid is removed. The results showed that $H$. suaveolens leaf powder gave acid insoluble ash of $6.39 \%$. Based on this result, it could be inferred that the reduction from total ash value is because the calcium oxalates and carbonates were soluble in hydrochloric acid and were thus removed. Water soluble ash value gave $1.16 \%$. Water soluble ash is relevant in quantifying the extraneous material that have been exhausted by water. It is an important indication of the presence of exhausted material 
substituted for the genuine article ${ }^{15,16}$. The sulphated ash value also produces a less consistent ash than the total ash. The extractive yields are used as means of evaluating crude drugs, the constituents of which are not readily estimated by other means. It is important to note that the amount of crude drug soluble in a given solvent is an index of it purity. The results showed that the constituents of $H$. suaveolens leaves are soluble in both alcohol (0.61\%) and water (1.67\%). Moisture content gave $11.7 \%$ at room temperature; this shows possible hydrolysis of active components when exposed to air.

\section{CONCLUSION}

The results presented in this study could serve as diagnostic parameters for proper identification as well as preparation of a monograph on Hyptis suaveolens Lamiaceae Linn. (Poit).

\section{ACKNOWLEDGMENT}

We appreciate the authors presented here and the fruitful results they were able to achieve. The authors thank Department of Pharmacognosy and Environmental Medicine and Department of Plant Science \& Biotechnology, University of Nigeria, Nsukka for providing the facilities used for the research.

\section{REFERENCES}

1. Azevedo N.R, Canpos I.F.P, Ferreira H.D, Portes T.A, Santos S.C, Seraphin J.C, Poaula J.R and Ferri P.H. Chemical variability in the essential oil of Hyptis Suaveolens. Phytochem. 2001; 57:733-736.

2. Abdullahi M., Muhammed G and Abdulkadir N.U Medicinal and economic plants of Nupe land. Jube-Evans books \& Publications. 2003;179.

3. Smitinand T., Thai Plant Names, The forest Hebarium, Royal Forest Department, Bangkok, Thailand, 2001.
4. Peerzada N., Chemical Composition of the essential oil of Hyptis Suaveolens. Molecule 1997; 2:165-168.

5. The Wealth of India (Raw Materials) vol. V, CSIR, New Delhi. 1964:159.

6. Dalziel M., Useful Plants of West Africa, crown Agents, London. 1937, 410-461.

7. Mabbereley D.J., The plant Book, Cambridge University Press, London 1990: 209-289.

8. Okonta E.O, Odoh E.U, Chukwube V, Okafor S.N and Ezugwu C.O. Phytochemical Investigation and Evaluation of Larvicidal property of leaf extracts of Hyptis Suaveolens(L.) Poit Against Aedes aegypti (Linn.) (Diptera; culicidae). (IOSR-JPBS). 2016; 11: 71-75.

9. Harbourne JBC, Phytochemical methods, Chapman and Hall, London, $1973 ; 279$.

10. Trease G.E and Evans W.C, Pharmacognosy, $14^{\text {th }}$ ed. Baillere Tindall, London, 1996; 86-540.

11. Evans W.C, Trease and Evans Pharmacognosy $15^{\text {th }}$ Edition, W.B Saunders and Co. 2002; 583-596.

12. Brain K.R, Turner T.D, In: The Practical Evaluation of Phytopharmaceuticals. M John Wright and sons, London, 1975; 145.

13. British Pharmacopoeia Her Royal Majesty Stationary Press, London, 2001; 1: A108-A110.

14. Onyekere P. F, Odoh U. E and Ezugwu C. O. Phytochemical Analysis and Anti-diabetic Activity of Leaf extract of Psydrax horizontalis Schum. \& thonn (Rubiaceae). Pharmacognosy Journal. 2020. 12(1): 1699-1706; doi: 10.5530/pj.2020.12.15

15. Ezejiofor M.A. Evaluation of Anti-microbial Activities of the volatile Oil of the seeds of Monodora Myristica, Dissertation, University of Nigeria, 2003, 97-103, 190-191.

16. Udodeme H.O, Odoh U.E, Ugwu P.N, Diovu E.O, Okonta E.O, Onyekere P.F, Ezugwu C.O. Pharmacognostic Studies of the Leaves of Stachytarpheta jamaicensis Linn. (Vahl) (Verbenaceae). International Journal of Pharmacognosy \& Phytochemical Research. 2016; 8(9);1503-1508 


\section{GRAPHICAL ABSTRACT}

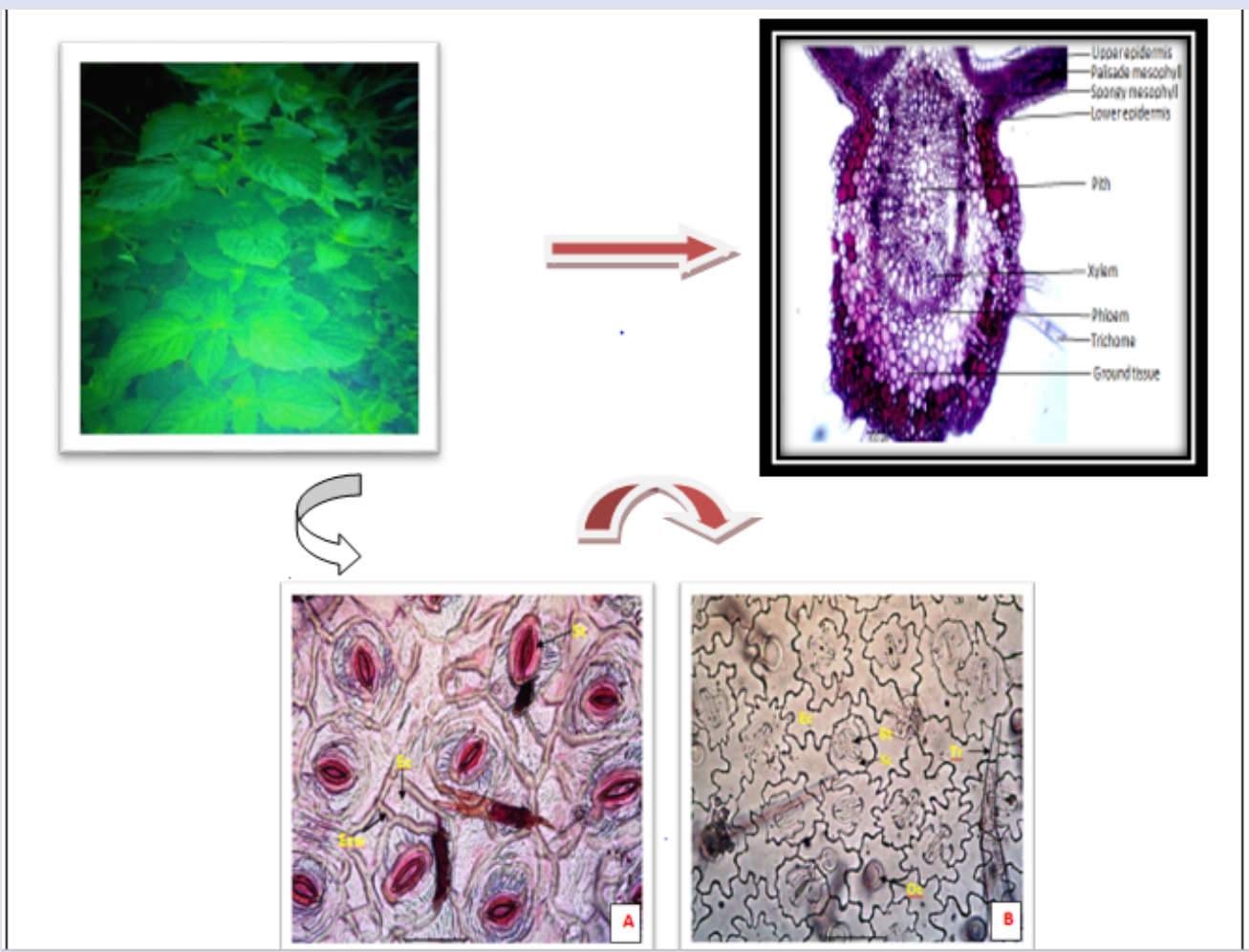

\section{ABOUT AUTHORS}

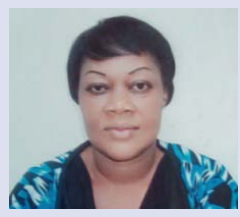

OKONTA, ELEJE OBOMA

Pharm. Mrs Okonta is a lecturer in the Department of Pharmacognosy \& Environmental Medicine, University of Nigeria, Nsukka. She holds a degree in Bachelor of Science in Biochemistry (B.Sc.), Bachelor of Pharmacy (B.Pharm) and Masters in Pharmacognosy (M.Pharm) from University of Nigeria. Her area of specialization is in phytoevaluation and her research interest is in the use of medicinal plants for the elimination of malaria in endemic regions of the world. She has to her credit 12 journal publications and many conference proceedings. She is also a member of the Nigeria Association of Pharmacists in Academia (NAPA) AND Pharmaceutical Society of Nigeria (PSN)

E-mail: eleje.okonta@unn.edu.ng

Telephone: +2348068405223

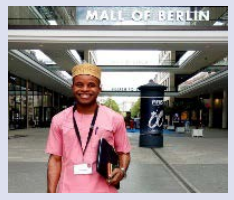

\section{ONYEKERE, PECULIAR FEENNA}

PECULIAR is a trained pharmacist, healthcare educator, lecturer, researcher and transformational speaker. He was a beneficiary of the DAAD In-country/In-region Scholarship during his Masters programme which he graduated with Distinction in Phytochemistry and was a participant in the 2018 EARTHS Summer School at Hamburg University of Applied Sciences, Germany.

Currently, he lectures in the Department of Pharmacognosy and Environmental Medicine at the University of Nigeria and is pursuing a Doctoral degree in Clinical Pharmacognosy. His research interest is in novel medicinal plants for the treatment of diabetes and oxidative diseases and has over 17 publications, 3 academic awards and more than 10 international conference presentations to his credit.

E-mail: peculiar.onyekere@unn.edu.ng, peculiar.onyekere@daad-alumni.de

Telephone: +2348068068346 


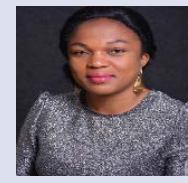

\section{UGWU, PATIENCE NGOZI}

Pharm. Patience is a lecturer in the Department of Pharmacognosy \& Environmental Medicine, Faculty of Pharmaceutical Sciences, University of Nigeria, Nsukka. She holds an OND degree in Computer Education, B.Pharm. in Pharmacy and M.Pharm in Environmental Pharmacognosy from the University of Nigeria, Nsukka.

Her research interest lies in Medicinal plant dosage forms, Environmental Pharmacognosy, Natural Products and Phytochemistry. She has six (6) different publications on these areas of research.

Email: patience.ugwu@unn.edu.ng

Telephone: +2348064153337

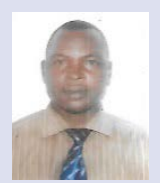

\section{CHUKWUBE, VINCENT OBISIKE}

Pharm. Vincent holds a Bachelor degree of Pharmacy and Masters degree in Pharmacognosy from University of Nigeria, Nsukka. Currently he is a Lecturer I in the Department of Pharmacognosy \& Environmental Medicine, University of Nigeria, Nsukka. His area of specialization is in phytochemistry and natural products. His research interest is in discovery of newer drugs and lead biomolecular compounds from structural proteins and botanicals for the global eradication of diabetes mellitus. With over nine publications to his credit, he is a merit award winner of the Pharmaceutical Society of Nigeria (PSN)

E-mail: vincent.chukwube@unn.edu.ng; pharmvinobisc@yahoo.co.uk

Telephone: +2348033426337

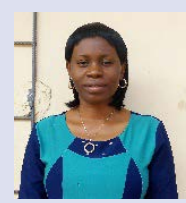

\section{UDODEME, HELEN OGECHUKWU}

Pharm. Helen graduated with a B.Pharm (Pharmacy) degree from Faculty of Pharmaceutical Sciences, University of Nigeria, Nukka (UNN) and also obtained her Masters degree in Pharmacognosy \& Environmental Medicine from the same institution. She was recently promoted to Lecturer I as an academic staff member of the Department of Pharmacognosy \& Environmental Medicine, University of Nigeria and currently running a Ph.D Programme on drug discovery against trypanosomiais. She has to her credit over seven publications in high rated impact factor journals.

Email: helen.udodeme@unn.edu.ng

Telephone: +2348036977153

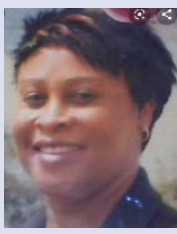

\section{ODOH, UCHENNA ESTELLA}

She is a Professor of Pharmacognosy \& Environmental Medicine. Her research interests include phytochemistry, natural product chemistry, drug evaluation and quality control. A supervisor to many undergraduate and postgraduate students in the Department with many publications to her credit.

Address: Department of Pharmacognosy \& Environmental Medicine, Faculty of Pharmaceutical Sciences,

University of Nigeria, Nsukka. 410001. Enugu State, Nigeria.

E-mail: uchenna.odoh@unn.edu.ng

Telephone No: +2348063831237

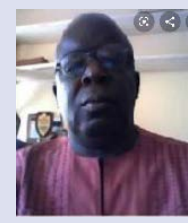

\section{EZUGWU, CHRISTOPHER OBODOIKE}

$\mathrm{He}$ is a Professor of Pharmacognosy \& Environmental Medicine. His research interests include ethnobotany and phytochemistry. He is the current Head of Department of Pharmacognosy \& Envrionmental Medicine. He has supervised many undergraduate and postgraduate students with many publications to his credit Affliation: Department of Pharmacognosy \& Environmental Medicine,

Faculty of Pharmaceutical Sciences, University of Nigeria, Nsukka. 410001. Enugu State, Nigeria.

E-mail: oechristo@yahoo.co.uk;

Phone No: +2348037786689

Cite this article: Okonta EO, Onyekere PF, Ugwu PN, Udodeme HO, Chukwube VO, Odoh UE, et al. Pharmacognostic Studies of the Leaves of Hyptis Suaveolens Linn. (Labiatae) (Poit). Pharmacog J. 2021;13(3): 698-705. 